\title{
A recent colonization of Dolichopoda cave crickets in the Poscola cave (Orthoptera, Rhaphidophoridae).
}

\author{
Camilla Bernardini *, Claudio Di Russo *, Mauro Rampini **, \\ Donatella Cesaroni * and Valerio Sbordoni *
}

\begin{abstract}
SUMMARY
We report a series of investigations carried out on a Dolichopoda population recently discovered in the Poscola cave and in some small caves nearby (Lessini Mountains, Vicenza). This population is located north of Po river, outside the present known geographic range of this genus in Italy. Morphology of the epiphallus corroborated by chromosome and allozyme analysis indicated that this population belongs to D. laetitiae. Study of the genetic structure of population in the Poscola area revealed high gene flow levels between Poscola and the other minor caves, suggesting the occurrence of a single expanding population. This finding as well as mark-recapture data on population size, migrations, age structure and habitat type strongly suggest that the Poscola population is the result of a recent colonization due to anthropocore dispersal.
\end{abstract}

\section{INTRODUCTION}

Colonization, i.e. the successful invasion of a new area (or habitat) by a species, is a process with important evolutionary consequences. Particularly, the study of colonization events of isolated habitat, such as caves or islands, because of their simplified ecology, represents a good opportunity to investigate any detectable evolutionary changes in animal and plant populations both from the ecological and the genetic point of view. However, for the cave habitat, only few experimental transplantations have been reported in the last forty years. These experiments include the transplantation of Amphipod Crustacean Niphargus virei in the Balme cave in French (Ginet, 1965), of the Cholevid beetles Speonomus longicornis, $S$. diecki, S. stygius and Bathysciola derosasi introduced respectively in the

* Dipartimento di Biologia, Università di Roma "Tor Vergata". Via della Ricerca Scientifica, 00133 Roma-Italy.

** Dipartimento di Biologia Animale e dell'Uomo, Università di Roma "La Sapienza". Viale dell'Università 32, 00185 Roma-Italy. 
Ramioul cave in Belgium (Bouillon \& Hubart, 1982; Tercafs \& Brouwir, 1991) and in the Patrizi cave in Italy (Patrizi, 1956) and of Dolichopoda linderi populations in two caves of southern France (Di Russo, 1993). Dolichopoda cave crickets were recorded in the Poscola cave for the first time in 1991 by one of us (M. Rampini). Previous records of cave crickets from this cave included Troglophilus cavicola and T. neglectus only (Bartolomei, 1957). The location of this cave, which is largely outside of the presently known range of Dolichopoda (Fig.1), and the low vagility of these crickets, usually limited to hypogean habitats, led us to hypothesize that the population presently inhabiting Poscola cave is the result of a recent colonization. In order to test this hypothesis and to detail the biology of this population, genetic and ecological studies were carried out throughout periodical sampling.

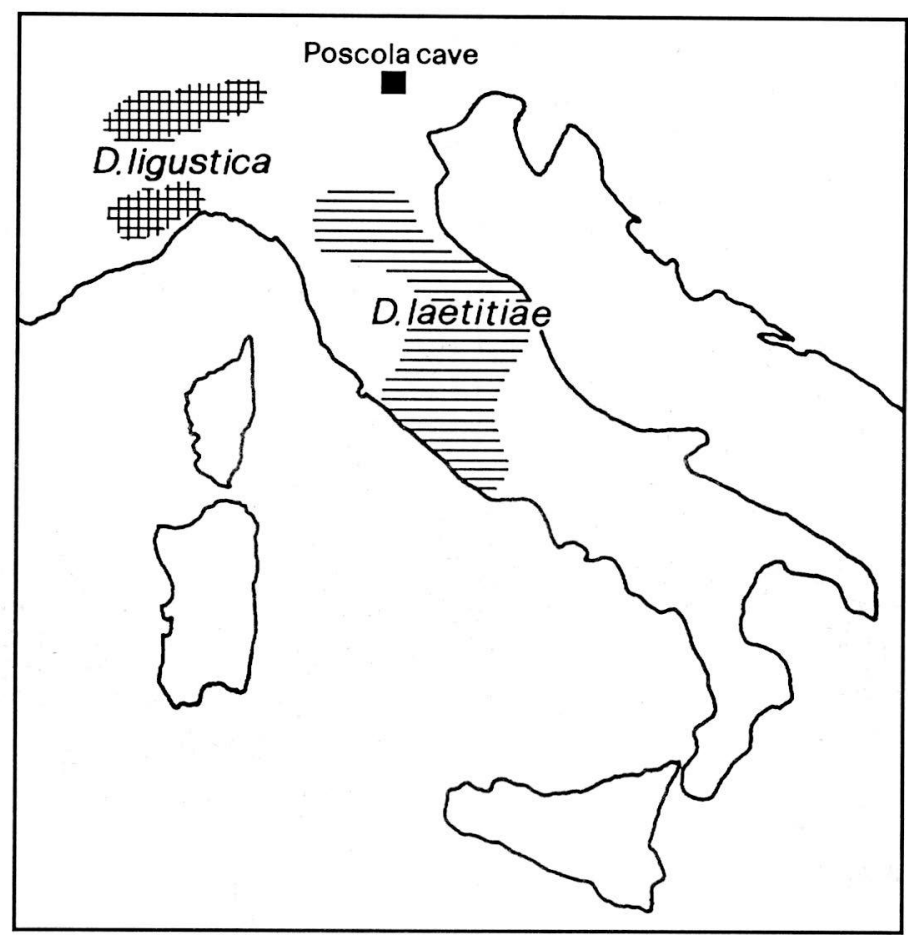

Fig. 1 - Geographic location of Poscola cave and distribution range of D.ligustica and D.laetitiae. 


\section{MATERIAL AND METHODS}

Geographical location and cave description.

Poscola cave (cave register number: $136 \mathrm{~V} / \mathrm{VI}$ ) belongs to a Karst system located at $275 \mathrm{~m}$ asl on the eastern slope of the Faedo-Casaron mountain near Priabona village (Lessini Mountains, Vicenza). The cave develops horizontally for $325 \mathrm{~m}$, showing two entrances. The main entrance opens near the garden of the Priabona church, while the smaller one is surrounded by a thick wood. Furthermore a stream springs near the secondary entrance and flows through the cave (Fig. 2).

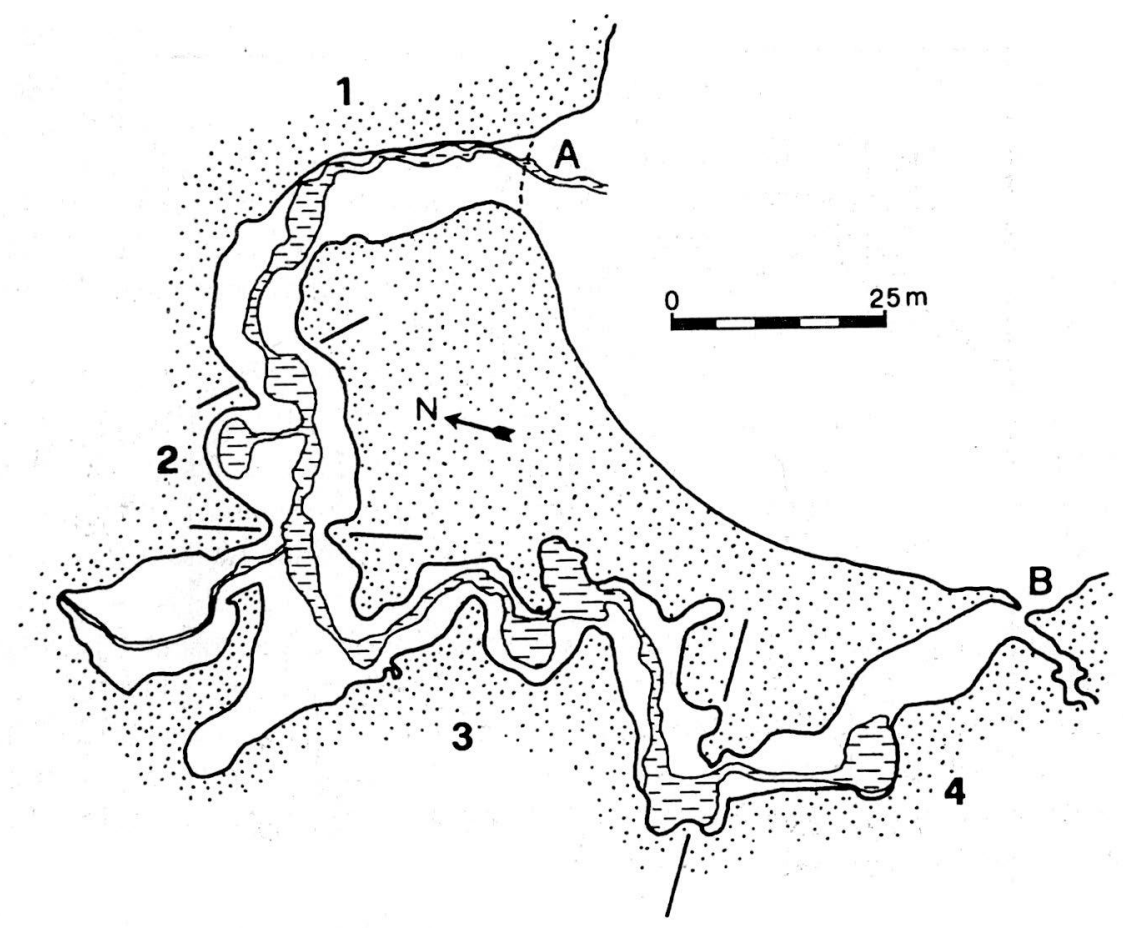

Fig. 2-Map of the Poscola cave: A, the main entrance; B, secondary entrance; 1,2,3, and 4, the different sectors for samplings. 
The chek list of the fauna of this cave, compiled by Fabiani (1904) and later completed by Bartolomei (1957), is here reported: Gastropoda (Oxychilus sp.); Copepoda (Speocyclops sp.); Isopoda (Androniscus dentiger, Armadillidium sp., Monolistra berica); Amphipoda (Niphargus stigius costozzae, Gammarus balcanicus); Decapoda (Astacus fluviatilis); Chilopoda (Lithobius sp.); Pseudoscorpionida (Chthonius sp.); Opiliones (Gyas sp.); Orthoptera (Troglophilus cavicola, T. neglectus); Coleoptera (Neobathyscia fabianii, Antisphodrus sp.); Lepidoptera (Scoliopteryx libatrix); Diptera (Culex sp.); Chiroptera and Rodentia.

Following our first record of Dolichopoda in 1991, several other small caves near the main Poscola cave were periodically checked for Dolichopoda occurrence. Out of 12 only 6 caves were inhabited by Dolichopoda: Poscola I (PSC 1), Poscola II (PSC 2), Poscola III (PSC 3), Poscola IV (PSC 4, $\left.n^{\circ} 1528 \mathrm{~V} / \mathrm{Vi}\right)$, Marchiori cave $\left(\mathrm{n}^{\circ} 579 \mathrm{~V} / \mathrm{Vi}\right)$, Buco sopra la cava (n॰2254 V/Vi) (Fig. 3).

\section{Epiphallus morphology}

Morphology of the epiphallus is the taxonomic character usually utilized to identify species in Dolichopoda (Baccetti \& Capra, 1959, 1970). Samples of $D$. laetitiae and $D$. ligustica were therefore examined for comparative analysis. These two species were considered because of their geographic distribution and their overall similarity.

Study samples were from Bunker near Muratone pass (LIG), PignaLiguria (D. ligustica) and Zigolo cave (ZIG), Castel dei Britti-Emilia; Drago cave (DRA), Apecchio-Marche; Bella cave (FSS1), Genga-Marche; Tana Termini cave (TER), San Marcello Pistoiese-Toscana; Nebbia cave (FUN), Fungaia-Toscana; Etruscan Mitreo (SUT), Sutri-Lazio (D. laetitiae).

After dissection the epiphallus was treated with $\mathrm{KOH}$ solution $(0.5 \mathrm{~N})$ and dehydrated in graded ethanol series. These structures, mounted on stubs, were coated with a thin layer of gold in a sputtering unit (MED010 sputter coater, Balzer Union). Observations were carried out with a Stereo Scan Cambridge 200 scanning electron microscope operating at $15 \mathrm{kV}$. Micrographs were taken on 120 Agfapan 25.

\section{Chromosome analysis}

Mitotic chrompsomes were obtained from male nymph crickets. After dissection in a proper solution $(\mathrm{NaCl} 0.7 \%, \mathrm{CaCl} 20.02 \%)$, testes were iso- 


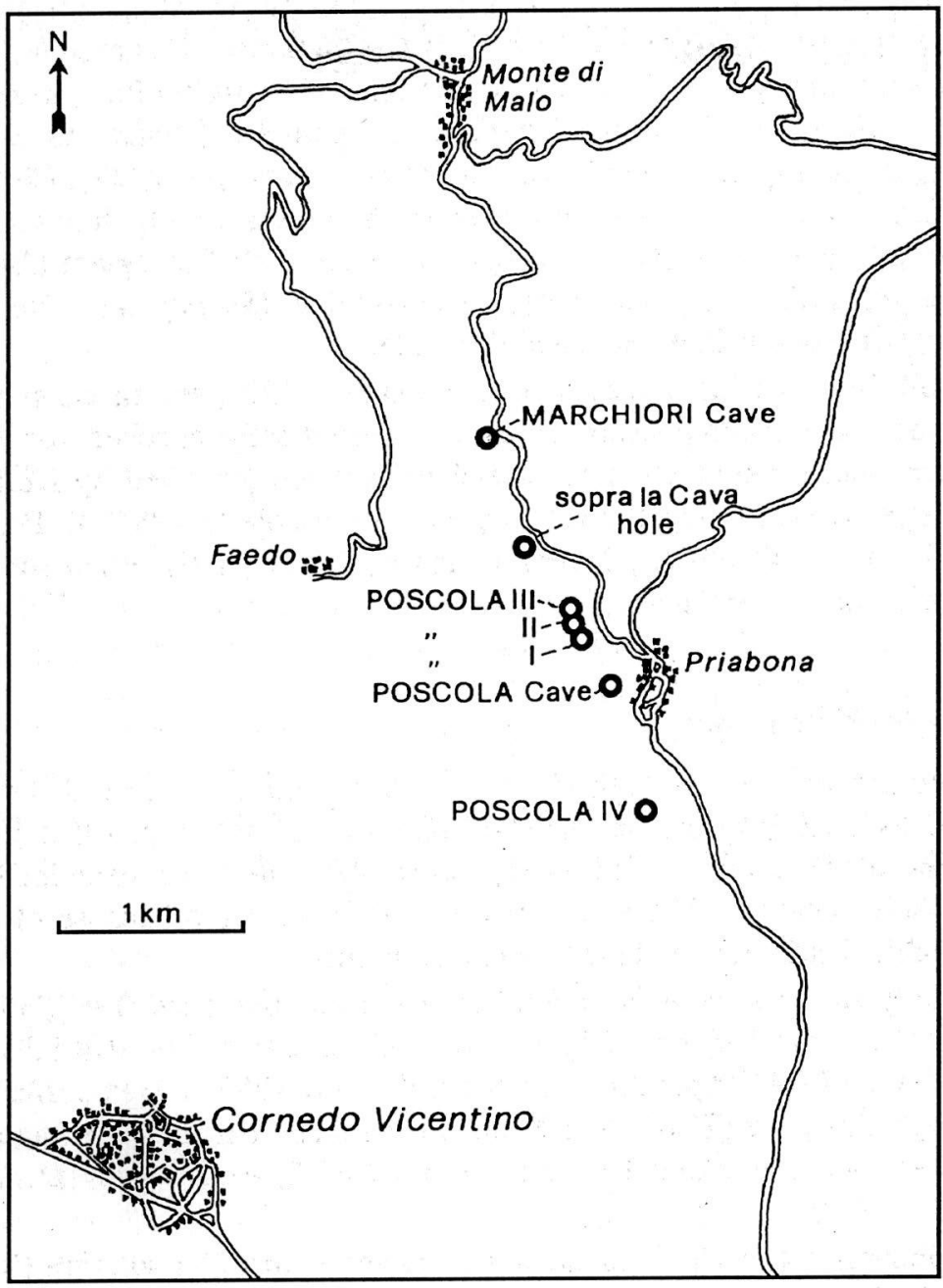

Fig. 3 - Detailed map of Poscola area. The main cave and the six small visited caves in the neighbourhood are indicated.

lated, fixed in methanol-acetic acid 3:1 for 30 sec., then incubated in a drop of acetic acid for $1 \mathrm{~min}$. Tissues were squashed under a siliconized coverslip which was removed with a razor blade after immersing the cytological preparation in liquid nitrogen. Chromosomes were stained with nucleophilic Giemsa solution (5\% in deionized water for $20 \mathrm{~min}$.) and 
observed with a Leitz Laborlux 12 microscope equipped with a 100/50W mercury lamp.

\section{Allozyme analysis}

The degree of genetic similarity between Poscola cave population and other populations of D.laetitiae was evaluated by means of allozyme polymorphisms. Samples of two D.laetitiae populations, from Pitigliano cave (PIT) in Tuscany and S. Giacomo cave (GIA) in Umbria, were collected and analysed for comparative purpose. On a narrower geographic scale, samples from some small caves near the Poscola cave (PSC1, PSC3 and PSC4) were also considered to investigate population genetic structure (Fig. 3). All samples were assayed electrophoretically for genetic variation at 19 gene loci: acidphosphatase (Acp), aldolase (Aldo), diaphorase (Dia), esterase (Est-1, Est-2), glutamate-oxaloacetatetransaminase (Got), glucosephosphateisomerase (Gpi), isocitratedehydrogenase (Idh-1, Idh-2), leucinoaminopeptidase (Lap-1, Lap-2), malatedehydrogenase (Mdh-1, Mdh-2), mannose-phosphateisomerase (Mpi), peptidase (Pep), phosphoglucomutase $(P g m)$, pyruvate-kinase $(P k)$, proteins $(P t)$. The methodology essentially followed technical procedures reported in Allegrucci et al. (1992) with minor modifications.

Allele frequencies, observed and expected heterozygosities, and genetic distances were calculated using the BIOSYS-1 program of Swofford and Selander (1981). Genetic distance indices were calculated using the Nei's (1978) algorithm.

F-statistics (Wright, 1951) was used to investigate the genetic structuring of Dolichopoda samples from the Poscola area, by using the procedure of Weir and Cockerham (1984) and the FSTAT program (ver1.2) developed by Jérôme Goudet, University of Losanna, Switzerland. The extent of gene flow was evaluated by means of $\mathrm{Nm}$ values, i.e. the average number of migrants exchanged per generation, estimated from the relationship: $\mathrm{F}_{\mathrm{ST}}=1 /(4 \mathrm{Nm}+1)$.

\section{Estimation of population size by seasonal samples}

Poscola cave was divided in four sectors (Fig. 2) to relate the spatial distribution of Dolichopoda to thermal condition of the cave and trophic resources availability. Air temperature of the four sectors was recorded seasonally by a digital thermometer $( \pm 0.1)$. 
Population size was estimated by mark-recapture method (Lincoln, 1930) modified for small population by Bailey (1951). This method was previously tested in several Dolichopoda populations (Carchini et al., 1983; Rampini et al., 1983).

According to Bailey (1951), population size $\mathrm{N}$ was calculated by [N = $\mathrm{M}(\mathrm{T}+1) /(\mathrm{R}+1)]$, where $\mathrm{M}$ is the number of marked individuals, $\mathrm{T}$ is the total number of recaptured individuals and $R$ is the total number of recaptured individuals previously marked.

Variance of the estimates was calculated as follow: $[\mathrm{V}(\mathrm{N})=$ $\left.\mathrm{M}^{2}(\mathrm{~T}+1)(\mathrm{T}-\mathrm{R}) /(\mathrm{R}+1)^{2}(\mathrm{R}+2)\right]$ and confidence limits (C.f.) are given by the relation [C.f. $= \pm t * \sqrt{ } V(N)$ ] with $t=1.96$ for $\alpha=95 \%$. Samplings were carried out every three months starting from March '94 to June ' 95. Additional samplings, conducted on December '92, June '93 and March '96, were also available. In order to record displacements inside the cave and migration outside the cave, crickets were marked with different colours in different sectors. Age structure of each sample was studied by means of individual metatibial length recorded with a vernier caliper.

\section{RESULTS}

\section{Taxonomic assessment of Poscola cave population}

The inspection of the epiphallus of Poscola specimens showed substantial differences from $D$. ligustica, because of its deep incision at the basal part of the structure, while its shape appeared to fall within the variation of D. laetitiae (Fig.5). Morphological similarity to D. laetitiae was also revealed by other structures as male X uroterga, subgenital plate and ovipositor in the female. However, because of a wide range of variation in these morphological structures within D. laetitiae (Sbordoni et al., 1979), chromosome and allozyme analyses were carried out to support taxonomic assignment.

Figure 4 illustrates mitotic chromosomes obtained from a nymph of Poscola population. A diploid number equal to 31 was established, with sex determination XX, XO. As found in other Dolichopoda species (A.P. Bianchi, pers. com.) a supernumerary chromosome occurred. Number and morphology of chromosomes appeared to match to D.laetitiae (Baccetti, 1958). On the contrary the Poscola karyotype differed from that of the geographically closest species, D.ligustica, which presents a diploid number of 30 chromosomes (Baccetti, 1982). 
Furthermore allozyme polymorphisms analysis showed a low level of genetic divergence between the Poscola population (PSC) and the two D.laetitiae populations (PIT and GIA), as indicated by D values (Nei, 1978) ranging from 0.031 to 0.054 . These values in Dolichopoda are usually found between conspecific populations (Sbordoni et al., 1985; Allegrucci et al., 1992). On the basis of these analyses we can safely assign the Poscola population to Dolichopoda laetitiae.

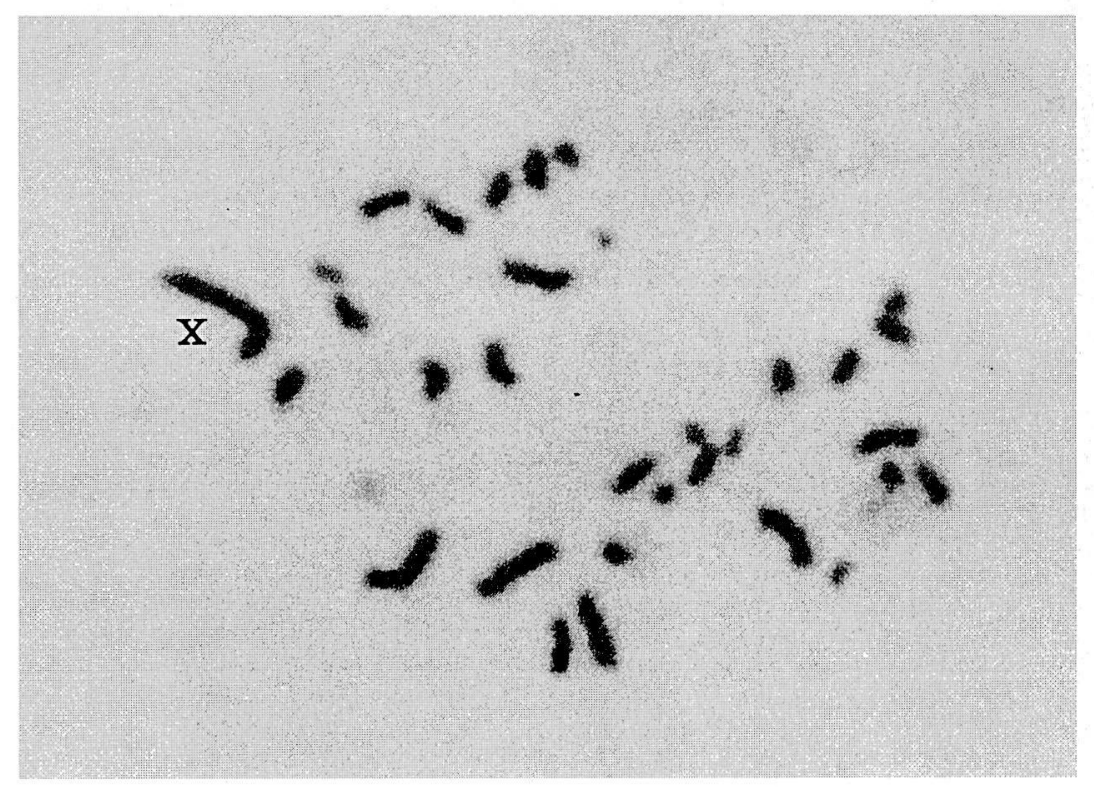

Fig. 4-Mitotic plate from a male nymph of Poscola cave. The X-chromosome is indicated.

\section{Population size}

Table 1 lists the number of cave crickets in Poscola cave estimated by mark-recapture method since December 1992 until March 1996. Estimates ranged between a minimum of 496 individuals (c.l. \pm 127) in June 1995 and a maximum of 1988 individuals (c.l. \pm 588 ) in October 1994. Population size showed strong variation apparently not related to any seasonal trends. 

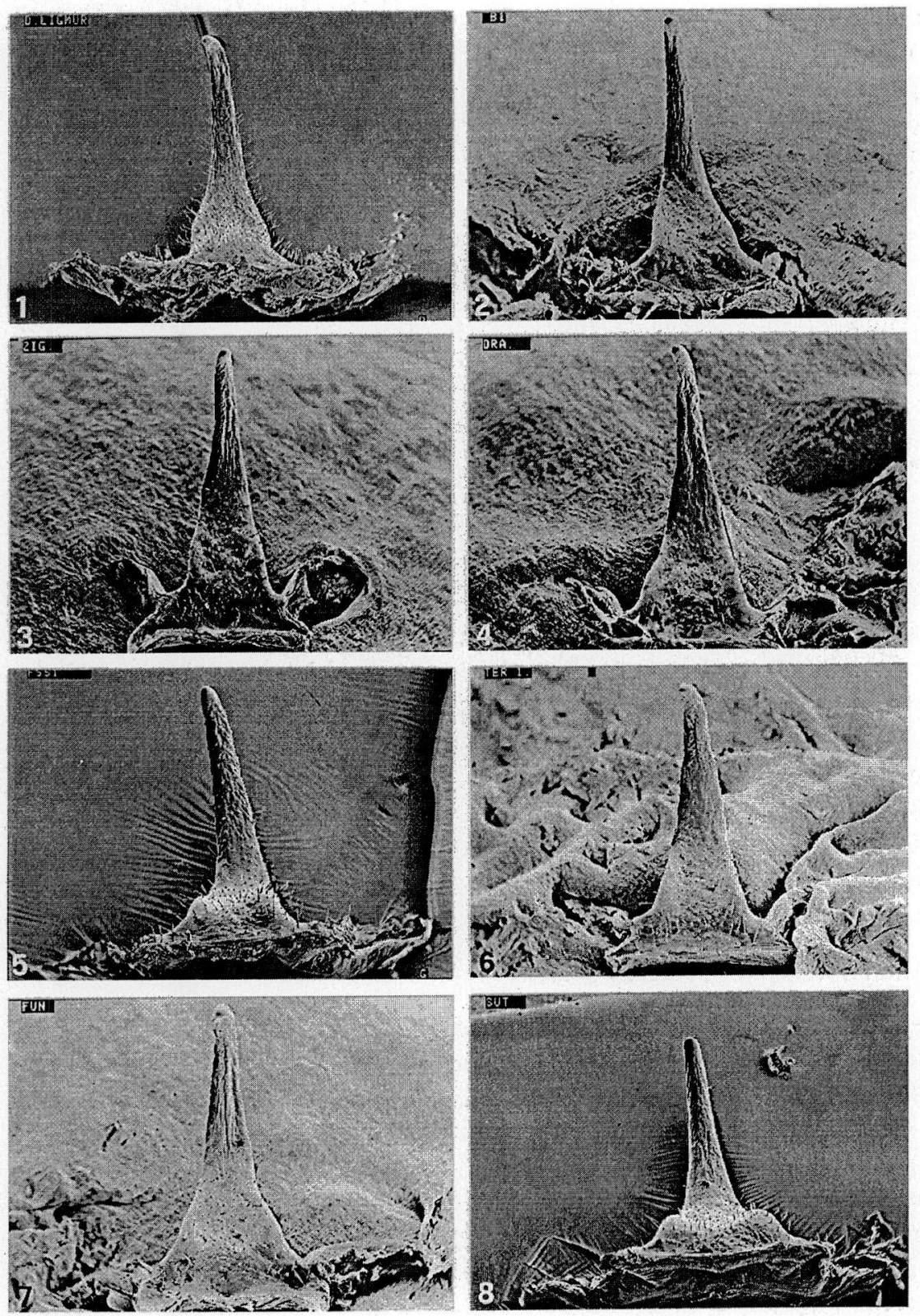

Fig. 5 - Scanning electron microscope photographs of the epiphallus: $1=D$. ligustica (LIG); 2=Dolichopoda from Poscola cave; 3-8=D. laetitiae, (3=ZIG, 4=DRA, 5=FSS1, 6=TER, $7=$ FUN, $8=$ SUT; for population symbols see text). 
Table 1 - Population size $(\mathrm{N})$ estimated in Poscola cave by mark-recapture method. $\mathrm{M}=$ marked individuals; $\mathrm{T}=$ total individuals recaptured; $\mathrm{R}=$ marked individuals recaptured; $\mathrm{V}=$ variance C.I. $=$ confidence limits

\begin{tabular}{lrrrrrr} 
& M & T & R & N & V & C.l.(+/-) \\
\hline Dec-92 & 256 & 283 & 79 & $\mathbf{9 0 9}$ & 7330 & 166 \\
Jun-93 & 188 & 283 & 32 & $\mathbf{1 6 1 8}$ & 67520 & 509 \\
Mar-94 & 183 & 163 & 37 & $\mathbf{7 9 0}$ & 12252 & 215 \\
Jun-94 & 182 & 252 & 40 & $\mathbf{1 1 2 3}$ & 25070 & 310 \\
Oct-94 & 259 & 283 & 36 & $\mathbf{1 9 8 8}$ & 90154 & 588 \\
Jan-95 & 513 & 360 & 98 & $\mathbf{1 8 7 0}$ & 25405 & 311 \\
Apr-95 & 527 & 418 & 116 & $\mathbf{1 8 8 7}$ & 21667 & 288 \\
Jun-95 & 173 & 105 & 36 & $\mathbf{4 9 6}$ & 4209 & 127 \\
Mar-96 & 167 & 144 & 22 & $\mathbf{1 0 5 3}$ & 7644 & 171 \\
\hline
\end{tabular}

\section{Age structure and sex-ratio}

Figure 6 reports the frequency distributions of metatibia length obtained from individual measures in seasonal samples. Individual growth showed a clear seasonal trend, resulting from the occurrence of different age groups in different periods of the year.

Adults start to emerge at the begining of summer and show a frequency peak in autumn, while in winter they disappear. During the winter, the population is composed only by nymphs of different age which stop growing because of dormancy. In autumn, two distinct choorts of individuals are clearly identifiable. A first one is mainly formed by adults, and a second by youngs and nymphs. The sex ratio for each of the samples was not statistically different from the ratio 1:1.

\section{Spatial distribution and migration}

Temperature variation in space and time is summarized in Table 2 . The sector 1 and 4 appeared rather variable with seasonal $\Delta \mathrm{T}$ ranging from $7.7^{\circ} \mathrm{C}$ to $9^{\circ} \mathrm{C}$. On the contrary sectors 2 and 3 appeared relatively more stable, with a $\Delta \mathrm{T}$ ranging between $4.6^{\circ} \mathrm{C}$ and $5.5^{\circ} \mathrm{C}$. Sector 1 showed a mean temperature relatively low $\left(10.2^{\circ} \mathrm{C}\right)$, while sector 4 , with a mean temperature of $13.5^{\circ} \mathrm{C}$, was close the optimum temperature $\left(15^{\circ} \mathrm{C}\right)$ of Dolichopoda life cycle (Di Russo \& Juberthie, 1995). According to these data sector 1 was seldom inhabited by Dolichopoda, most of which occured in the sector 4 in every season. Only in winter the spatial distribution of crickets appeared more heterogeneous as a consequence of displacement of Dolichopoda inside of the cave, particularly in the sectors 2 and 3. Markrecapture data also confirmed these observations. In fact, several crickets, 

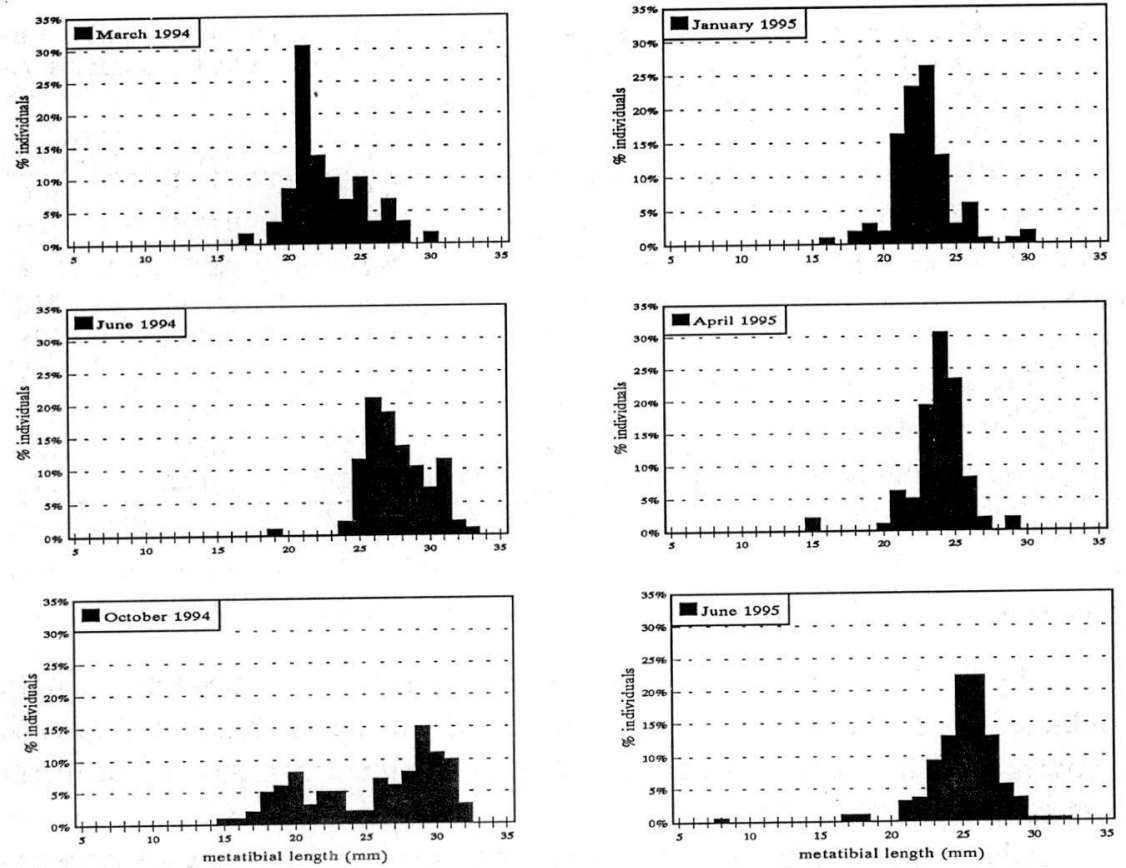

Fig. 6-Comparison of age structures in periodical samples from Poscola cave population. Frequency distributions are based on metatibia length.

marked in autumn and winter and coming from the sectors close to the entrances (1 and 4), were recaptured in the sectors 2 and 3. On the contrary, 10 individuals, marked in winter in the two inner sectors, were found in the sector 4 on spring and summer.

Dolichopoda were also discovered in the small caves near Poscola cave. Migration between these caves can occur, as established by recapture in PSC1 of one individual previously marked in the main cave. Apparently only one out of these small caves (PSC3) showed a stable population. This was estimated by periodical counts ranging between 200 and 400 individuals. In the summertime, occasional sights of Dolichopoda, were also recorded outside caves.

Table 2-Summary of thermal condition in the four sectors of Poscola cave

\begin{tabular}{lllll} 
& $\min { }^{\circ} \mathbf{C}$ & $\max { }^{\circ} \mathbf{C}$ & $\operatorname{mean}$ & $\Delta \mathbf{T}\left({ }^{\circ} \mathbf{C}\right)$ \\
\hline sector 1 & 5 & 14 & 10.2 & 9 \\
sector 2 & 7.7 & 13.2 & 11.5 & 5.5 \\
sector 3 & 11 & 15.6 & 12.8 & 4.6 \\
sector 4 & 11.6 & 19.3 & 13.5 & 7.7 \\
\hline
\end{tabular}




\section{Genetic structure}

Allele frequencies at 19 loci calculated for the four population samples (PSC, PSC1, PSC3 and PSC4) are reported in Table 3. Different samples showed allele frequencies quite similar at most loci, and genetic distance values were very low in any pairwise comparison, ranging from 0.000 to 0.003 .

The analysis of the genetic structuring for these nearby populations was performed by using $\theta$ (Weir and Cockeram, 1984) as $\mathrm{F}_{\mathrm{ST}}$ estimator. The global $\theta$ value was 0.009 , suggesting absence of population heterogeneity in the study area, and the deriving $\mathrm{Nm}$ product was 27.52. Accordingly, $\mathrm{Nm}$ values for single pairwise comparisons between samples appear rather high (all of the six values >14), suggesting that several migrants are exchanged per generation between these four population units. In Table 3 estimates of genetic variability at 19 gene loci in all study samples are also reported. On the whole, expected heterozygosity $(\mathrm{He})$ ranged from 0.111 to 0.174 .

Table 3 - Allele frequencies, observed (Ho) and expected (He) heterozygosities for the 4 population samples from Poscola area; $\mathrm{n}$ refers to the number of assayed individuals.

\begin{tabular}{|c|c|c|c|c|c|c|c|c|c|c|c|}
\hline Locus & & PSC & PSC1 & PSC3 & PSC4 & Locus & & PSC & PSC1 & PSC3 & PSC4 \\
\hline$A c p$ & $\begin{array}{l}\mathrm{n} . \\
\mathrm{A} \\
\mathrm{C}\end{array}$ & $\begin{array}{l}16 \\
0.969 \\
0.031\end{array}$ & $\begin{array}{l}24 \\
0.917 \\
0.083\end{array}$ & $\begin{array}{l}33 \\
0.955 \\
0.045\end{array}$ & $\begin{array}{l}28 \\
1.000 \\
0.000\end{array}$ & Lap-1 & $\begin{array}{l}\text { n. } \\
\text { C } \\
\text { D }\end{array}$ & $\begin{array}{l}14 \\
0.321 \\
0.536\end{array}$ & $\begin{array}{l}21 \\
0.452 \\
0.524\end{array}$ & $\begin{array}{l}34 \\
0.309 \\
0.618\end{array}$ & $\begin{array}{l}27 \\
0.296 \\
0.611\end{array}$ \\
\hline \multirow[t]{2}{*}{ Aldo } & $\mathrm{n}$. & 16 & 24 & 34 & 29 & & E & 0.143 & 0.024 & 0.074 & 0.093 \\
\hline & $\begin{array}{l}\text { A } \\
\text { n. }\end{array}$ & $\begin{array}{l}1.000 \\
16\end{array}$ & $\begin{array}{l}1.000 \\
23\end{array}$ & $\begin{array}{l}1.000 \\
31\end{array}$ & $\begin{array}{l}1.000 \\
26\end{array}$ & Lap-2 & n. & $\begin{array}{l}14 \\
0821\end{array}$ & 12 & 27 & 24 \\
\hline \multirow{2}{*}{ Dia } & $\begin{array}{l}\text { A } \\
\text { B }\end{array}$ & $\begin{array}{l}0.156 \\
0.719\end{array}$ & $\begin{array}{l}0.152 \\
0.848\end{array}$ & $\begin{array}{l}31 \\
0.226 \\
0.694\end{array}$ & $\begin{array}{l}20 \\
0.173 \\
0.808\end{array}$ & & $\begin{array}{l}\text { A } \\
\text { B } \\
\text { C }\end{array}$ & $\begin{array}{l}0.821 \\
0.143 \\
0.036\end{array}$ & $\begin{array}{l}0.958 \\
0.000 \\
0.042\end{array}$ & $\begin{array}{l}0.963 \\
0.037 \\
0.000\end{array}$ & $\begin{array}{l}0.812 \\
0.167 \\
0.021\end{array}$ \\
\hline & C & 0.125 & 0.000 & 0.081 & 0.019 & $M d h-1$ & $\mathrm{n}$. & 16 & 24 & 34 & 25 \\
\hline \multirow[t]{2}{*}{ Est-1 } & n. & $\begin{array}{l}16 \\
0.906\end{array}$ & $\begin{array}{l}22 \\
0.977\end{array}$ & & & & $\begin{array}{l}\text { A } \\
\text { B }\end{array}$ & $\begin{array}{l}0.187 \\
0.812\end{array}$ & $\begin{array}{l}0.000 \\
0.958\end{array}$ & $\begin{array}{l}0.029 \\
0.926\end{array}$ & $\begin{array}{l}0.140 \\
0.840\end{array}$ \\
\hline & C & 0.094 & 0.023 & 0.076 & 0.125 & & D & 0.000 & 0.042 & 0.044 & 0.020 \\
\hline \multirow[t]{3}{*}{ Est-2 } & $\begin{array}{l}\mathrm{n} . \\
\mathrm{A}\end{array}$ & $\begin{array}{l}16 \\
0.062\end{array}$ & $\begin{array}{l}24 \\
0.125\end{array}$ & $\begin{array}{l}34 \\
0.279\end{array}$ & $\begin{array}{l}29 \\
0.103\end{array}$ & $M d h-2$ & n. & $\begin{array}{l}16 \\
0.937\end{array}$ & $\begin{array}{l}24 \\
1000\end{array}$ & $\begin{array}{l}34 \\
0.985\end{array}$ & 29 \\
\hline & B & 0.750 & 0.792 & 0.603 & 0.776 & & D & 0.062 & $\begin{array}{l}1.000 \\
0.000\end{array}$ & $\begin{array}{l}0.985 \\
0.015\end{array}$ & $\begin{array}{l}1.000 \\
0.000\end{array}$ \\
\hline & C & 0.187 & 0.083 & 0.118 & 0.121 & Mpi & n. & 16 & 24 & 34 & 28 \\
\hline \multirow[t]{3}{*}{ Got } & $\mathrm{n}$. & 14 & 23 & 32 & 23 & & B & 1.000 & 1.000 & 1.000 & 1.000 \\
\hline & A & 0.036 & 0.022 & 0.016 & 0.022 & Pep-1 & $\mathrm{n}$. & 16 & 24 & 33 & 29 \\
\hline & B & 0.964 & 0.978 & 0.984 & 0.978 & & A & 1.000 & 1.000 & 1.000 & 1.000 \\
\hline \multirow[t]{4}{*}{ Gpi } & n. & 16 & 24 & 34 & 29 & Pgm & n. & 16 & 23 & 34 & 27 \\
\hline & A & 0.094 & 0.000 & 0.044 & 0.000 & & A & 0.062 & 0.022 & 0.015 & 0.019 \\
\hline & B & 0.406 & 0.479 & 0.426 & 0.569 & & B & 0.906 & 0.978 & 0.985 & 0.981 \\
\hline & C & 0.500 & 0.521 & 0.529 & 0.431 & & C & 0.031 & 0.000 & 0.000 & 0.000 \\
\hline \multirow[t]{2}{*}{$I d h-I$} & n. & 16 & 24 & 34 & 29 & $P k-2$ & $\mathrm{n}$. & 16 & 23 & 34 & 25 \\
\hline & C & 1.000 & 1.000 & 1.000 & 1.000 & & A & 1.000 & 1.000 & 1.000 & 1.000 \\
\hline \multirow[t]{4}{*}{$I d h-2$} & n. & & & & & $P t-4$ & n. & 16 & 24 & 34 & 29 \\
\hline & B & 1.000 & 1.000 & 1.000 & 1.000 & & A & 1.000 & 1.000 & 1.000 & 1.000 \\
\hline & & & & & & $P t-5$ & $\mathrm{n}$. & 16 & 24 & 34 & \\
\hline & & & & & & & $\mathrm{A}$ & 1.000 & 1.000 & 1.000 & 1.000 \\
\hline Ho & & 0.181 & 0.098 & 0.126 & 0.124 & He & & 0.174 & 0.111 & 0.138 & 0.139 \\
\hline
\end{tabular}




\section{DISCUSSION AND CONCLUSIONS}

The present genetic and morphological investigations carried out on Dolichopoda from the Poscola area allowed us to assign them to D. laetitiae, a species whose northern limit is represented by Po river (Baccetti, 1982). The occurrence of this species to the north of Po river was never reported in the literature. In addition, the absence of Dolichopoda from Poscola cave was witnessed by earlier investigations (Bartolomei, 1957). As a consequence, a quite recent colonization of the Poscola cave seems highly realistic. Concerning the mechanism of colonization, the most plausible hypothesis should imply an anthropocore dispersion. Unintentional transplantation of eggs, nymphs or even adults is a likely event in Dolichopoda. This mechanism has been hypothized to explain the occurrence of Dolichopoda schiavazzii in cellars and other artificial caves in the Argentario Promontory, where $D$. baccettii diverged and speciated in insular allopatric condition. Since the present spread of $D$. schiavazzii in this area is limited to the neighbouring of the Passionisti Abbey in the inner part of the Promontory, the occurrence of this species in this area has been explained with anthropocore dispersion (Allegrucci et al., 1982). Alternative hypotheses implying active colonization by Dolichopoda appear unlikely, because of lack of records within a wide area north and south of Po river, which apparently represents a geographic barrier for these crickets. Previous studies on geographic variation of molecular and morphological traits proved that both geographic distribution and speciation processes in Dolichopoda have been strongly affected by such river barriers (Sbordoni et al., 1991; Cesaroni et al., 1996).

If only few individuals, or even a single female, founded the Poscola cave population, an expected consequence could be a reduction in genetic variability of the present population. The allozyme survey showed that heterozygosity in PSC $(\mathrm{He}=0.174)$ is comparable to the levels of genetic variability reported for other Dolichopoda populations (Sbordoni et al., $1985,1991)$. However, these findings do not necessarily conflict with the hypothesis of a small propagule founding the Poscola population. In fact, several other factors can counterbalance the loss of genetic diversity due to founder effect. Particularly, Nei et al. (1975) developed a general model concerning the effects of bottlenecks on the heterozygosity in respect to the intrinsic rate of growth (r) of the populations. According to this model, for any given mutation rate, a $\mathrm{r}$ value $\leq 0.1$ should correspond to a high decrease of genetic variability in the population. On the contrary for $r$ values $\approx 1$ the average heterozygosity appears weakly affected by 
bottleneck. Being estimated $\mathrm{r}$ value ranging between 0.7 and 1 in Dolichopoda spp. including D. laetitiae (Di Russo, 1993), it is reasonable to argue that founder effect, whichever number of founders was, did not played a significant role in changing the level of genetic variability of the Poscola cave population.

Mark-recapture experiments proved that present Dolichopoda population is abundant and wealthy, confirming the successful achievement of the cave colonization. Population size reached a maximum value of 2000 individuals. This estimated size is probably close to the carrying capacity of the cave. However, relevant variations in population size, observed in various periods of the year, were probably due to either migration outside the cave or winter grouping. In fact crickets were commonly found in suitable habitats (either small caves or wood floor) surrounding the main cave. These migrations, chiefly occurring to search food outside the cave, can represent the main reason for Dolichopoda dispersal across other small caves in the area. The very low $F_{S T}$ estimate $(\theta=0.009)$ calculated for the four population samples indicates complete lack of genetic structuring of population units which actively exchange individuals and genes. The degree of genetic structuring between samples from Poscola area is comparable to that found between subpopulations of D.laetitiae within a single cave (Cappellani, unpublished data) or in adjacent artificial hypogea (Sansotta, 1993). Since we expect that $F_{S T}$ is positively related to the age of the populations and to the occurrence of extrinsec barriers to migration, the value obtained for the Poscola populations also supports a recent colonization and present active dispersion of crickets in this area.

Short distance active dispersion of Dolichopoda in other areas of foothills of the Alps appears to be favoured by the prevailing mesophilic bioclimatic conditions. This is clearly showed by recent records of new population units of $D$. ligustica septentrionalis near Bergamo whose settlement may have not occurred before 1980 (Comotti, 1982; pers. com.).

Population age structure showed a typical seasonal trend as often found in Dolichopoda populations inhabiting artificial caves with trophic resources largely represented by vegetable matters seasonally available outside caves. This kind of age structure might be unexpected in a natural limestone cave as Poscola, relatively rich in bat guano deposits. In similar situations a costantly heterogeneous age structure is generally found as an adaptation to exploit resources inside cave and to reduce intraspecific competition (Di Russo et al., 1987; Carchini et al., 1991; De Pasquale et al., 1995). However, preliminary data on feeding habits of these crickets indicated a diet mainly based on vegetable matters (L. De Pasquale, 
pers.com.). Even the spatial distribution of crickets inside the cave supports dependence upon external resources. In fact, in spring and summer, most of crickets were located near the secondary entrance surrounded by mesophilic wood, a suitable environment to move and search food. These findings suggest that the seasonal age structure revealed in this population might be the consequence of both recent colonization of the Poscola area and bioclimatic conditions that favour exploitation of trophic resources outside the cave.

Since Dolichopoda cave crickets show a typical semivoltine life cycle (Boudou Saltet, 1971; Di Russo et al., 1987), it could be expected that a single colonization event might determine lack of mobile individuals during 6-9 months, corresponding to the embryonic development, and emergence of adults every two years. On the contrary, observed phenology clearly showed the occurrence of two choorts formed by individuals of different age overlapping each other in autumn and the emergence of adults every summer. This finding suggests that choort overlap can arise in a few generations, as a possible consequence of variability in the duration of embryonic diapause, nymphal dormancy and asincrony in laying eggs. Di Russo (1993) described a similar situation in two experimentally transplanted populations of Dolichopoda linderi in France, which, starting from a little number of founders, showed choort overlap arised in less than 10 generations.

\section{ACKNOWLEDGEMENTS}

We thank Erminio Piva, Isabel Ferrari, Giuseppe Peretto of the Club Speleologico Proteo (Vicenza) and Claudia Tedeschi for the useful collaboration in all the steps of field study. We also thank Niccolò Falchi for drawing pictures.

\section{REFERENCES}

ALlegruCCI, G., A. CACCONE, D. CESARONI, M. COBOLli SBORDONI, E. DE MATTHAEIS, and V. SBORDONI. 1982. Natural and experimental interspecific hybridization between populations of Dolichopoda cave crickets. Experientia 38: 96-98.

ALLEGRUCCI, G., A. CACCONE, D.CESARONI, and V. SBORDONI. 1992. Evolutionary divergence in Dolichopoda cave crickets: a comparison of single copy DNA hybridization data with allozymes and morphometric distances. J. Evol. Biol. 5: 121-148.

BACCETTI, B. 1958. Notulae Orthopterologicae.IX. Osservazioni cariologiche sulle Dolichopoda italiane. Redia 43: 315-327.

BACCETTI, B. 1982. Ortotteri cavernicoli italiani (Notulae Orthopterologicae.XXXVI.). Lav. Soc. Ital. Biogeogr. Verona. 1978 (n.s.); 6: 195-200.

BACCETTI, B. and F. CAPRA. 1959. Notulae Orthopterologicae. XII. Revisione delle specie italiane del genere Dolichopoda. Bol. (Orth. Rhaph.). Redia, 44: 165-217. 
BACCETTI, B. and F. CAPRA. 1970. Notulae Orthopterologicae. XXVII. Nuove osservazioni sistematiche su alcune Dolichopoda italiane esaminate anche al microscopio elettronico a scansione. (Orth. Rhaph.). Mem. Soc. Ent. Ital., 48: 351-365.

BAILEY, N.T.J. 1951. On estimating the size of mobile population from recapture data. Biometrika, 38: 293-306.

BARTOLOMEI, G. 1957. La grotta della Poscola. Rassegna Speleologica Italiana, 9: 51-59.

BOUILLON, M. and J.M.HUBART. 1982. Premiers resultats d'une expèrience de transplantation de cavernicoles pyréneens dans une grotte de Belgique. Bull. Cherch. Wall. 25: 97-106.

BOUDOU-SALTET, P. 1971. Observations du cycle vital, en elevage, d'un Orthoptére cavernicole Dolichopoda linderi Duf. Bull. Soc. Hist. Natur. Toulouse. 107: 301-305.

CARCHINI, G., M.RAMPINI, C.SEVERINI, and V.SBORDONI. 1983. Population size estimates of four species of Dolichopoda in natural and artificial caves of Central Italy (Orthoptera, Rhaphidophoridae). Mem. Biospeol. 10: 341-347.

CARCHINI, G., C.DI RUSSO, and V.SBORDONI. 1991. Contrasting age structures in cave cricket populations: patterns and significance. Ecol. Entomol. 16: 305-314.

CESARONI, D., P.MATARAZZO, G.ALLEGRUCCI, and V.SBORDONI. 1996. Comparing patterns of geographic variation in cave crickets by combining geostatistic methods and Mantel tests. J.Biogeogr.: in press.

COMOTTI, G. 1982. Fauna cavernicola orobica $-1^{\circ}$. Presenza di Dolichopoda sp. nel bergamasco (osservazioni ecologiche e biologiche). OL. BUS - Speleo Club Orobico C.A.I. - BG. 5 (5): 21-39.

DE PASQUALE, L., D. CESARONI, C. DI RUSSO, and V. SBORDONI. 1995. Trophic niche, age structure and seasonality in Dolichopoda cave crickets. Ecography 18: 217-224.

DI RUSSO, C. 1993. Adaptations et divergence evolutive des populations des Dolichopoda des Pyrènèes Orientales (Groupe D.linderi). These de doctorat. Universitè P. Sabatier Toulouse III.

DI RUSSO, C., A. VELLEI, G. CARCHINI, and V. SBORDONI. 1987. Life cycle age structure of Dolichopoda populations (Orthoptera, Rhaphidophoridae) from natural and artificial cave habitats. Boll. Zool., 54: 337-340.

DI RUSSO C. and C. JUBERTHIE. 1995. Effetto della temperatura sullo sviluppo embrionale in Dolichopoda (Orthoptera, Rhaphidophoridae). Fragm. Entomol. 27 (1): 51-59.

FABIANI, R. 1904. Contributo alla conoscenza della fauna delle grotte di Monte di Malo, Priabona e Cereda. Riv. It. Speleologia 2 (1).

GINET, R. 1965. Expérience de colonisation souterrain aquatique par Niphargus (Crust. Amphipodae); premiers résultats biologiques. Bull. Soc. Zool. Fr. 90: 581-588.

LINCOLN, F.C. 1930. Calculating waterfowl abundance on the basis of banding returns. Circ. U.S. Dep. Agric., nx 118.

NEI, M. 1978. Estimation of average heterozygosity and genetic distance from a small number of individuals. Genetics, 89: 583-590.

NEI, M., T. MARAUYAMA, and R. CHAKRABORTY. 1975. The bottelneck effect and genetic variability in populations. Evolution, 29: 1-10.

PATRIZI, S. 1956. Introduzione ed acclimatazione del Coleottero Catopide Bathysciola derosasi Dod. in una grotta laziale. Le Grotte d'Italia, 1:303.

RAMPINI, M., G.CARCHINI, and V.SBORDONI. 1983. Ecologia di una popolazione di Dolichopoda geniculata (Costa) in una cavità artificiale del sottosuolo di Roma. (Orthoptera, Raphidophoridae). Fragm. Entomol., 17: 85-99.

SBORDONI, V., G. ALLEGRUCCI, D. CESARONI, and G. SAMMURI. 1978. Sulla posizione sistematica e le affinità di Dolichopoda "etrusca" in base a dati elettroforetici. Fragm. Entomol., 15: 67-78.

SBORDONI, V., G. ALLEGRUCCI, D.CESARONI, M. COBOLLI SBORDONI, and E. DE MATTHAEIS. 1985. Genetic structure of populations and species of Dolichopoda cave crickets: evidences of peripatric divergence. In V.Sbordoni (ed.), Genetics and Ecology in Contact Zones of Populations, Boll. Zool., 52: 95-114.

SBORDONI, V., G. ALLEGRUCCI, and D. CESARONI. 1991. A multidimensional approach to the evolution and systematics of Dolichopoda cave crickets, pp.171-179. In 
G.Hewitt, A.W.B.Johnston and J.P.W.Young (eds.), Molecular Techniques in Taxonomy, NATO Asi Series, Vol. H57. Springer, Berlin, Heidelberg.

SANSOTTA, A. 1993. Grilli cavernicoli e tombe etrusche: struttura genetica di una popolazione in rapporto all'eterogeneità dell'habitat. Tesi di Dottorato di Ricerca in Biologia Evoluzionistica. Università di Roma "Tor Vergata".

SWOFFORD, D. and R.B. SELANDER. 1981. BIOSYS-1. A computer for the analysis of allelic variation in genetics. University of Illinois. Urbana, Illinois.

TERCAFS, R. and C. BROUWIR. 1991. Population size of Pyrenean troglobiont coleopters (Speonomus species) in a cave in Belgium. Int. J. Speleol. 20: 23-35.

WEIR, B.S. and C.C. COCKERHAM. 1984. Estimating F-statistics for the analysis of population structure. Evolution, 38: 1358-1370.

WRIGHT, S. 1951. The genetical structure of populations. Ann. Hum. Genet., 15: 323-354. 